DOI: $10.17805 /$ zpu.2017.2.14

\title{
«Коня! Коня! Полцарства за коня!»: вольный перевод шекспировского эптонима в тезаурусе русской культуры *
}

\author{
Б. Н. ГАЙДИН \\ МОСКОВСКИЙ ГУМАНИТАРНЫЙ УНИВЕРСИТЕТ
}

В статье затрагивается проблема научного описания крылатых слов и выражений в рамках тезаурусного подхода. Кратко представлена концепция термина «эптоним», предложенная Л. П. Дядечко. Это позволило подтвердить некоторые выводы о специфике данной разновидности констант культуры.

Прослеживается судьба вольного перевода на русский язык знаменитой фразы короля Ричарда III "A horse! a horse! my kingdom for a horse!" $(V, 4)$ из одноименной исторической хроники У. Шекспира. Приведены контексты из литературных произведений XIX-XXI вв., а также из текстов двух песен, в которых можно найти приписываемый актеру Я. Г. Брянскому перевод. Проанализировано его влияние на других переводчиков. Неточность передачи шекспировского оригинала, по мнению автора, только способствовала распространению эптонима «Коня! Коня! Полцарства за коня!» в отечественном культурном тезаурусе. Данный пример также свидетельствует, что в отличие от афоризмов крылатые слова могут в зависимости от контекста менять смысл, а также иногда подвергаются словесным трансформациям.

Статья подготовлена на основе доклада автора на II Академических чтениях памяти Вл. А. Лукова «Тезаурусы и тезаурусная сфера» (Московский гуманитарный университет, 29 марта 2017 г.).

Ключевые слова: У. Шекспир; Шекспир в России; «Ричард III»; тезаурусный подход; тезаурус русской культуры; переводы Шекспира; Я. Г. Брянский; крылатые слова; крылатые выражения; эптонимы

\section{BВЕАЕНИЕ}

$\mathrm{K}$ ак известно, отдельные выразительные и емкие фразы получают столь широкое распространение, обретают такую популярность, что зачастую могут терять связь с первоисточником и употребляться в самых разных контекстах. Со временем в силу тех или иных социокультурных причин некоторые из них становятся чрезвы-

* Подготовлено в рамках проекта «Шекспир в современной русской культуре: национальное и глобальное», осуществляемого при поддержке Совета по грантам Президента РФ (MK-1182.2017.6).

The article was prepared within the framework of the project "Shakespeare in Contemporary Russian Culture: The National and Global" with support from the Council for Grants of the President of Russian Federation (MK-1182.2017.6). 
чайно популярными, т. е. входят в ядро культурной памяти большого числа людей, другие, наоборот, уходят на периферию тезауруса носителей той или иной культуры ${ }^{1}$.

Конечно, если в системе школьного образования изучению основных гуманитарных предметов уделяется достойное внимание, то и спустя годы большинство населения будет помнить авторов самых известных крылатых выражений, афоризмов, цитат и т. А. Значительное влияние на коллективную память общества оказывают популярные литературные произведения, спектакли, песни, фильмы и т. А., которые могут «воскресить» в ней, казалось бы, давно забытые, но полные смысла и красоты фразы.

В современной лингвистике не утихают споры о крылатых словах и выражениях как единицах языка. На наш взгляд, было бы небезынтересно рассмотреть некоторые из лингвистических концепций, раскрывающих особенности крылатых слов и выражений, для изучения этой «разновидности гуманитарных констант» (Ауков В., $\Lambda$ ков Вл., 2013: 85) в рамках общегуманитарного тезаурусного подхода.

Например, $\Lambda$. П. Аядечко для обозначения крылатых слов и выражений предложи-

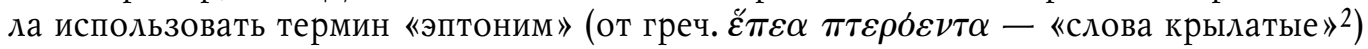
(см.: Аядечко, 2002). Под эптонимом исследователь понимает цитату из какого-либо текста, которая включается в иной контекст как «готовая единица большого экспрессивного заряда в силу ассоциативно-генетической связи с первоисточником» (Аядечко, 2006: 192). Эптонимы имеют следующие признаки: 1) узнаваемость, массовая воспроизводимость в различных ситуациях; 2) «специфическое происхождение» (автор или, по крайней мере, текст-источник известны); 3) высокая степень экспрессивности; 4) «культурно-национальная и социумная стереотипизированность»; 5) тенденция к краткости, языковой экономии (Аядечко, 2003: 32; см. также, например: Салахатдинова, 2014).

В целом некоторые характеристики эптонимов схожи с теми, которые выделяют Вал. А. и Вл. А. Ауковы по отношению к крылатым словам как культурным константам: 1) обладают обобщенным содержанием; 2) известны, понятны и значимы Аля носителей той или иной культуры; 3) свидетельствуют о некотором уровне культуры как тех, кто их использует, так и тех, кто способен их понять (Иуков Вл., Ауков, 2009: 235).

\section{ШЕКСПИРОВСКИЕ ЭПТОНИМЫ}

У. Шекспир подарил человечеству большое количество афоризмов, крылатых слов и выражений, которые выступают как «вербальные свидетельства константных скреп культуры» (Ауков, Ауков Вл., 2013: 85). Фразы его героев “То be, or not to be: that is the question" ( «Быть или не быть, вот в чем вопрос»), "A plague on both your houses” ( Чума на оба ваши дома!»), “All the world is a stage...” ( «Весь мир - театр») и др. известны далеко за пределами англоязычных стран и употребляются в самых разных контекстах (см., например: Aphorisms from Shakespeare, 1812; McQuain, Malless, 1998; The Arden dictionary ..., 2013).

Благодаря талантливым переводчикам Шекспир стал неотъемлемой частью русской культуры, по выражению И. С. Тургенева, «вошел в нашу плоть и кровь» (Тургенев, 1986: 327). Мы «не без права» можем гордиться историей переводов произведений британского драматурга и поэта на наш родной язык.

Конечно, далеко не все (особенно представители молодежи) с легкостью определят авторство указанных и иных крылатых выражений. Еще меньшее количество лю- 
дей вспомнит, в каком произведении их можно найти и какому персонажу они принадлежат. Тем не менее многие из этих «вечных фраз» прочно укоренились на отечественной почве и подобно вечным образам (см., например: Ауков, Ауков Вл., 2008а: Электронный ресурс; Гайдин, 2008, 2009abcd, 2011; Волкова, 2008; Николаев, 2012; «Вечные» сюжеты и образы ... , 2015) играют значимую роль в трансляции культурноисторического опыта и, соответственно, в процессе сохранения культурной целостности социума.

Рассмотрим пример перевода на русский язык одной из самых известных шекспировских строк - знаменитой фразы короля Ричарда III “A horse! a horse! my kingdom for a horse!” $(\mathrm{V}, 4)$ из одноименной исторической хроники.

\section{ИСТОРИЯ ПЕРЕВОАА Я. Г. БРЯНСКОГО \\ И ЕГО ОТРАЖЕНИЕ В РУССКОЙ КУАБТУРЕ}

Вольный перевод «Коня! Коня! Полцарства за коня!» прочно закрепился в тезаурусе русской культуры, став наиболее популярным и известным из когда-либо предложенных вариантов. Как указывает В. В. Серов, впервые это крылатое выражение появляется «в стихотворном переводе (1833) актера Якова Григорьевича Брянского (1790-1853)», который он выполнил для своего бенефиса, состоявшегося 23 января 1833 г., «не с оригинала, а с французского прозаического перевода, поэтому он неточен» (Энциклопедический словарь ..., 2005: 364). По мнению исследователя, на него также могла оказать влияние традиция русских народных сказок, в которых герою в награду обычно обещаны не только царская дочь в жены, но и «полцарства в придачу».

Ю. А. Аевин отмечает, ссылаясь на воспоминания И. И. Панаева, что Я. Г. Брянский не владел иностранными языками, поэтому воспользовался подстрочным пере-

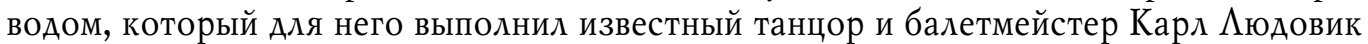
Аидло (Charles-Louis Didelot; тж. известен как Шарль Ауи Фредерик Аидло) (Иевин, 1965: 264). Однако сомнительно, что Аидло знал русский язык настолько хорошо, что мог перевести на него пьесу Шекспира с английского. По крайней мере, В. С. Баевский прямо указывает, что «Аидло не знал русского языка, и русские сюжеты (например, когда он ставил балеты по первым поэмам Пушкина) для него перелагали по-французски» (Баевский, 1986: 142). Таким образом, можно предположить, что Я. Г. Брянский все же имел достаточный уровень знания французского языка, который позволил ему сделать переложение шекспировского «Ричарда III».

При всех недостатках этого вольного поэтического перевода, его значение для русского театра сложно переоценить. Я. Г. Брянский пошел на ряд значительных изменений, сокращений и дополнений шекспировского текста, однако «его "Ричард III" на фоне дюсисовских переделок имел основание считаться “подлинным” Шекспиром. И таково было мнение публики» (Иевин, 1965: 266). Его исполнение роли короля-горбуна в шекспировской трагедии не снискало успеха, однако его перевод заслужил определенное признание среди отечественных любителей Шекспира и оказал влияние на других актеров. Возможно, именно пример Я. Г. Брянского повлиял на В. А. Каратыгина, который, как известно, сам переводил и переделывал пьесы иностранных авторов. Ему принадлежат переводы «Короля $\Lambda$ ира (1837) и «Кориолана» (1840) (там же: 283$)$.

В январе 1835 г. П. С. Мочалов сыграл главную роль в постановке «Жизнь и смерть Ричарда III» в переводе Я. Г. Брянского и смог добиться определенного успеха. Через 
пять лет Мочалов получил признание широкой публики, вновь использовав переложение старшего коллеги (см.: там же: 289). Возможно, именно этот успех послужил причиной того, что рассматриваемая нами строка из Шекспира в переводе Брянского обрела значительную популярность и со временем превратилась в крылатое выражение, которое чаще всего используют, говоря «о настоятельной просьбе или желании получить что-л., принеся в жертву многое» (Шулежкова, 2011: 557).

Так, именно исполнение П. С. Мочаловым роли Ричарда III нашло отражение в стихотворении А. А. Григорьева «Искусство и правда» (1854):

И помню, как в испуге диком

Он леденил всего меня

Отчаянья последним криком:

«Коня, полиарства за коня! »

(Григорьев, 2001: 111; курсив источника. - Б. Г.; см.: Аевин, 1965: 294-295).

В литературе можно найти еще более ранний пример использования варианта перевода, предложенного Я. Г. Брянским: А. А. Бестужев-Марлинский употребил его в путевом очерке «Аорога от станции Алмалы до поста Мугансы» (цикл «Кавказские очерки»), впервые опубликованном в 1835 г. в журнале «словесности, наук, художеств, промышленности, новостей и мод» книгоиздателя А. Ф. Смирдина под редакцией О. И. Сенковского «Библиотека для чтения»:

Румяная заря, прокравшись въ землянку на цыпочкахъ и не тревожа замка, сквозь разсълину двери, давно ужъ хозяйничала и егозила вокругъ моей кровати, а я еще бралъ на храпокъ у Морфея утренніе маки. Наконецъ я почувствовалъ на своихъ щекахъ свђжій поцълуй богини, и весело встрепенулся. За ней, - она въ поле, 一 играетъ, рђзвится, вђетъ своею газовою мантильею, брызжетъ душистою росою: потомъ вдаль розовою перчаткою и взвиласъ въ поднебесье жаворонкомъ.

\section{- «Коня, коня! Полцарства за коня!» \\ И борзый конь взвился подо мною}

(Марлинский, 1835: 34).

Отметим, что в примечании писатель отсылает читателя к шекспировскому оригиналу из «Ричарда III» (там же).

Впоследствии русские переводчики попытались предложить более точные эквиваленты: «Коня! коня! Престол мой за коня!» (А. В. Аружинин в 1862 г.; см.: Шекспир, 1899: 439); «Коня, коня! Венец мой за коня!» (А. А. Радлова в 1935 г.; см.: Шекспир, 1957: 577), «Коня! Коня! Корону за коня!» (Б. Н. Цейтин в 1958 г.; см.: Шекспир, 1958: 169; М. А. Аонской в 1976 г.; см.: Шекспир, 1988: 450), «Коня, коня! Престол мой за коня!» (Г. Е. Бен в 1997 г., см.: Шекспир, 1997: 201) и др. Однако никто из них не смог превзойти по популярности одну «из тех замечательных вольностей, что лучше отвечают духу подлинника, чем самый точный перевод» (Урнов, 2011: Электронный ресурс). Таким образом, не удивительно, что перевод Я.Г. Брянского и различные авторские варианты именно со словом «полцарства» можно найти в большом числе художественных произведений, мемуаров, научных статей и т. п.

К примеру, И. С. Тургенев обыграл варианты перевода данной шекспировской строки в своей поэме «Помещик» (1845; впервые опубл. 1846): 

Нет! Нет! Мы сбросим наши цепи, Вернемся снова к вам, о степи!
И вот - за бешеных коней
Отдав полцарства, даже царство -
Иетим за тридевять полей
В сороковое государство!..

И. И. Аажечников в очерке «Несколько заметок и воспоминаний по поводу статьи “Материалы для биографии А. П. Ермолова"» (1864) писал: «Спешу броситься на клок сена и, убаюканный расходившимся от качки на лошади волнением крови, погружаюсь в глубокий сон. Шекспиров Ричард отдавал полцарства за коня, а я не взял бы

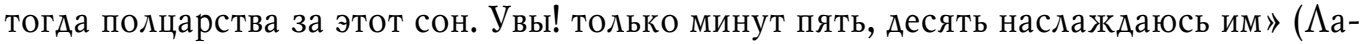
жечников, 1989: 447).

Революционер и журналист В. В. Кельсиев использует эту фразу в своих воспоминаниях «Пережитое и передуманное»: «Загремълъ засовъ, забрявалъ звонокъ, загрохотала дверь, - вмбсто всякихъ растягаевъ, лимбургскаго сыру и бульоновъ, несутъ мнъ шайку вчерашняго отвара неопредъленнаго цвета, вкуса и неописанного ни въ одной поварской книгъ. "Коня, коня, полцарства за коня", - удобствъ, удобствъ, а свободы покуда не нужно!» (Кельсиев, 1868: 161).

$\Lambda$. И. Шестов выбрал именно этот вариант для своей работы «Шекспир и его критик Брандес» (1898): «Во всъхъ рьчахъ римскаго вождя мы не найдем ничего, что сравнилось-бы съ рьчью, которую произноситъ англійскій король передъ посльднимъ сраженіемъ. Одно восклицаніе его: “коня, коня - полъ царства за коня!” изобличаетъ такую душевную мощь, которая поразила бы самого Марція» (Шестов, 1898: 164).

В XX в. количество примеров использования данного эптонима еще более возрастает. К примеру, А. В. Амфитеатров употребляет его в своем фельетоне «Несторова летопись за 1899 год» (1900; опубл. 1903), написанном на квазиславянском языке: «Игры же бъсовстіи отыгравше, сотвори воевода псковской, предводитель дворяньства сый, жратву велію. И позваше къ трапезь вси сладкопьвци, стихослагатели, мужи, куранти издающи и пишущи, книжници и учители людстіе и прочіе, иже рекутъ себе литератори, а такожде бахари и скоморохи. Аухманову же Надежду болярыню, да Фаресова Александра не позва. И оскорбися духъ ихъ, и восхотьша бъжати отъ Святыя горы, и, подъ дождемъ бродяще и за свой коштъ колбасу псковскую жующе, вопіяша жалостне: коня, коня! полцарства за коня!» (Амфитеатров, 1903: 280).

Сатирик И. $\Lambda$. Оршер (литературный псевдоним О. $\Lambda$. А’’p) использовал его в своей работе о русской истории «Россия» (в другой редакции «Русская история»; глава «Русь-Империя»; миниатюра «Петр-редактор»), которая вошла в известный сборник черного юмора «Всеобщая история, обработанная “Сатириконом”» (1909):

Министры горевали:

- Некому восхвалять наши действия. Полцарства за коня... виноват, за писателя!

(цит. по: Всеобщая история ... , 2005: 584)

Русский политический и общественный деятель В. В. Шульгин вспоминает о фразе шекспировского Ричарда III в своих мемуарах «Годы. Воспоминания члена Государственной Аумы», размышляя о роли коней в истории и своей собственной судьбе: 
Может ли конь оказывать влияние на политику?

Ставя этот вопрос, я исключаю того коня, на котором скачет Георгий Победоносец. Этот святой был изображен на гербе Москвы. Что его конь сопряжен с историей России, это самоочевидно. Но я ищу связи менее мистической. Полумистической является легенда, рассказанная Пушкиным в знаменитой балладе «Песнь о вещем Олеге». «Полцарства за коня!» - воскликнул один английский король. Менее известен конь Каравулик, который благодаря быстроте своего бега спас беглеца от гнева гнавшегося за ним разъяренного его отца, турецкого султана Баязида I Молниеносного.

Знаменит Буцефал - конь Александра Македонского. И вообще много можно найти коней, вошедших в историю.

Естественно, Я хотел бы сделать историческим моего коня Ваську. Я когда-нибудь напишу его правдивое жизнеописание. Но сейчас я спешу и ограничусь заявлением: мой конь Васька несомненно сыграл некоторую роль на выборах во вторую Государственную Ауму. Больше ничего не скажу.

(Шульгин, 2002: 32).

Советский писатель Василь Быков употребляет фразу в повести «Журавлиный крик» (белор. «Жураўліны крык», 1959) в разговоре солдат, находящихся на полях Великой Отечественной войны. Причем в устах пэтээровца Витьки Свиста можно уловить также отсылку к известным словам Гамлета “What a piece of work is a man!" (II, 2; к примеру, в переводе М. А. Аозинского они звучат следующим образом: «Что за мастерское создание - человек!»; см.: Шекспир, 1936: 61), с которыми, однако, персонаж повести Быкова не согласен:

- Эх, ярина зеленая, думаю иногда и диву даюсь, как это неважнецки человек устроен, - рассудительно заговорил Витька Свист, вороша щепкой уголья. - Есть много, хочется еще больше. А нет ничего, какой-нибудь пустяк - мечта. Вчера под Озерками, когда нас утюжили танки, я только и мечтал: скорей бы стемнело. Казалось, все бы отдал за одну минуту темноты. А теперь вот и немцев нет, и танков не слыхать, так хочется еще и тепла, и жратвы. Чудно...

- Открыл Америку, - буркнул Овсеев. - Еще Шекспир сказал: «Коня, коня! Полцарства за коня!» Понимаешь? За коня. Припечет, так захочешь...

(Быков, 1985: 49).

Поэтесса Т. И. Олейникова в 1970-1971 гг. написала «юношескую поэму» «Прощай». Свое произведение она во многом построила, используя выразительный стилистический прием повтора, в том числе анадиплосис. В качестве первой части данной фигуры речи автор использовала «как в сказке той», а в качестве второй - «полцарства за коня!». В этом примере, на наш взгляд, сильнее отразилось влияние традиций русского фольклора, чем истории рецепции шекспировского наследия в России:

11.

Мне - идолопоклоннице огня,

Не верящей ни в чёрта и ни в Бога,

Играть с огнём. Остерегись меня.

Я жгу костёр у твоего порога.

$<\ldots>$

Иишь добрый конь выносит из огня.

Как в сказке той - полцарства за коня!..

12.

Как в сказке той: «Полцарства за коня!..»-

Был щедрым царь, когда затеял мену... 
Конь был игрив! И грива - будто пена!..

Как щедр был царь! - но был упрямым князь!..

Вот так и я. Щедрот боюсь твоих...

Я не княжна, но ты царишь отныне

Над домом, одиноким и пустынным,

Над садом этим, что давно утих.

Что мне полцарства! — Я тебе веду

Авух златогривых - два степные ветра!

Мне - Царство всё!.. Но на твою беду -

Из двух смертей я для одной бессмертна.

Мне снова жить. Я приняла решенье.

За боль вознагради меня прощеньем.

$<\ldots>$

15.

Ты так легко мне говоришь: «Прощай»...

И я иду по утреннему саду.

$<\ldots>$

Как в сказке той, - полцарства за коня, За боль вознагради меня прощеньем

И незабвеньем награди меня

(Олейникова, 1992: 200-202).

В 1973 г. в сборнике «Клуб 12 стульев» был опубликован юмористический рассказ В. Е. Бахнова «Савушкин, который никому не верил». В нем старший экономист Савушкин меняет вместо коня свой мотоциклет «Ява» на полцарства некоего явившегося ему в полночь короля:

Ровно в полночь старшего экономиста разбудил громкий стук в дверь. Поспешно натянув полосатую пижаму, он выбежал из дачи и в неясном призрачном свете луны увидел какого-то короля. Трудно объяснить, почему Савушкин решил, что перед ним именно король. Однако он не ошибся.

- Нас предали! - воскликнул король, устало опустившись на крыльцо и вытирая лоб кружевными манжетами. - Армия разбита, а мой верный конь пал, не выдержав бешеной скачки. Коня! Полцарства за коня!

- Сколько? - переспросил старший экономист.

- Пол.

- Но, знаете, у меня нет коня. У меня есть только мотоциклет «Ява».

- Иадно, подайте мне «Яву», - поспешно согласился король. - О небо, небо!

- И, ловко вскочив на мотоцикл, он включил зажигание, дал скорость и скрылся в ночной тьме.

Все это Савушкин на следующее утро рассказал нам, страшно гордясь своей находчивостью и широтой натуры. $<. .>$ И тут зазвонил телефон. $<. .>$ Но на этот раз звонил король. Звонил, чтобы узнать у Савушкина, куда принести причитающиеся ему полцарства

(Бахнов, 1973: 33-35).

Под названием «Полцарства за коня» в 1982 г. была издана повесть И. М. Мельниченко (Мельниченко, 1982).

В 1983 г. в журнале «Сибирские огни» было опубликовано стихотворение поэтессы О. И. Мухиной «Средь свиста стрел и пиршества булата...», в котором это крылатое выражение является лейтмотивом: 
Средь свиста стрел и пиршества булата,

То ль отступая, то ль врагов тесня,

Варуг, спешенный, один король когда-то

Вскричал: - Коня! Полцарства за коня!

Мы можем рассудить, что он зарвался,

Что вряд ли после заплатил сполна.

Но если речь идет о целом царстве,

То половина - сходная цена.

Сменялись войны, государства, лица,

И, латами тяжелыми звеня,

Какой-то вовсе неимущий рыцарь

Хрипел: - Коня! Полцарства за коня!

Он чувствовал, как ноги каменеют, -

Верхом - он бог, а пешему - беда.

И за душой дублона не имея,

Он был предельно искренним тогда.

Когда спастись - конь вынесет из боя,

Когда догнать - конь полетит вперед.

Вот так, четвероногою, порою

Судьба пред человеком предстает.

Забыт король, но не забылось слово,

И если жизнь к земле пригнет меня,

Я помню суть и повторяю снова:

— Коня! Коня! Полцарства за коня!

(Мухина, 1983: 39)

В 1991 г. был опубликован роман «Авор» А. Аьвова (А. А. Бинштейна, написан в 1968-1972 гг.; Аьвов, 1991abc). В нем больному Иону Овсеичу Аегтярю во сне среди прочих является образ страшного горбуна, требующего себе коня:

Вечером, как предсказывала сестра, жар действительно усилился, труднее стало дышать, принесли подушку с кислородом, сделали укол. Иона Овсеич пытался заснуть, два или три раза удавалось, но тут же, от сильного толчка, просыпался, в голове всё путалось, какие-то жандармы, Полина Исаевна, немцы в зеленых касках, одноногий Котляр, сумасшедший Граник со своей улыбкой, в ушах гудело, свистело, гремело, словно балаган или дикий шабаш; уродливый горбун, лицо было мучительно знакомое, падал с лошади, ноги застряли в стременах, и кричал диким голосом: «Коня! Полцарства за коня!»

(Иьвов, 1991с: 143)

\section{ВАИЯНИЕ ЭПТОНИМА «КОНЯ! КОНЯ! ПОАЦАРСТВА ЗА КОНЯ! » НА ПЕРЕВОАЧИКОВ}

Перевод Я. Г. Брянского оказал сильное влияние не только на русскую театральную традицию3 ${ }^{3}$ Переводчики произведений других авторов использовали фразу шекспировского Ричарда III в своем творчестве. Так, в переводах исторического романа А. Аюма «Королева Марго» (1845), выполненных Е. Ф. Коршем («Король то бросал трубить, чтобы голосом натравливать собак, то переставал натравливать, чтобы тру- 
бить в рог. Весь мир перестал для него существовать. Если бы под ним пала лошадь, он крикнул бы, как Ричард III: “Полцарства - за коня!” »; Аюма, 1992: 256) и Я. Глумбергом ( «Весь свет перестал существовать для Карла. Если бы его лошадь отказалась служить, он крикнул бы, как Ричард III: “Полцарства - за коня!Ф»; Аюма, 2014: Электронный ресурс), находим «Полцарства - за коня!», хотя в оригинале - «Венец мой / Мою корону за коня!» («Ma couronne pour un cheval!»; Dumas, 1847: 318).

Интересно, что в пьесе «Пер Гюнт» (1867) Г. Ибсен вкладывает в уста главного героя фразу «Mit Rige, - mit halve Rige for en Hest!» (Ibsen, 1867: 14; см. об этом, например: Logeman, 1917: 210), т. е. буквально «Мое царство, — полцарства моего за коня!» Но как минимум в двух русских переводах пьесы мы обнаружим только «полцарства»: П. Г. Ганзен и его супруга А. В. Ганзен предложили «Впередъ! Полцарства за коня!» (Ибсен, 1909: 330), а П. М. Карп — «Ныне полцарства отдам за коня» (Ибсен, 1972: 139).

В романе Г. Уэллса «Колёса фортуны» (1896) Ауглас Уиджери, спрашивая у мальчишек, есть ли возможность где-нибудь поблизости нанять экипаж, восклицает: «Тhеre's not a cab, not a go-cart, in sight. <...> It's a case of a horse, a horse, my kingdom for a horse» (Wells, 1896: 223). В русском же переводе Т. А. Кудрявцевой и В. А. Ашкинази снова находим следующее: «Здесь нет ни кэба, ни телеги, - сказал Уиджери. - Вот уж в самом деле: коня, коня, полцарства за коня!» (Уэллс, 1964: 536).

А. В. Ауначарский в статье «Гёте и его время» опять же выбрал этот вариант при переводе цитаты из Гёте на русский, хотя сам писатель цитирует Шекспира по-немецки дословно: «Ein Pferd, ein Pferd! Ein Königreich für ein Pferd!» (Goethes Gespräche, 1909: 216):

Может быть вы думаете, что мне чужды великие идеи свободы, народа, отечества? Эти идеи часть нашего существа. $<\ldots .>$ Прокламации иностранцев о наших я сам нахожу превосходными. Ax, ах, коня, коня, - полцарства за коня!

Но коня ему не дали. Ему дали полцарства, «пол великого герцогства» Аали, но коня, чтобы руководить какими-то великими политическими атаками, ему не дали

(Ауначарский, 1932: 16).

\section{ЭПТОНИМ «КОНЯ! КОНЯ! ПОАЦАРСТВА ЗА КОНЯ! » В СОВРЕМЕННОЙ РОК-МУЗЫКЕ}

В песне известного отечественного рок-музыканта В. Р. Цоя «Невеселая песня», вышедшей в 1989 г. на альбоме «Звезда по имени Солнце», также есть отсылка к знаменитой фразе короля Ричарда III «A horse! a horse! my kingdom for a horse!» в переводе Я. Г. Брянского:

\footnotetext{
...Глядя в жидкое зеркало луж,

На часы, что полвека стоят, На до дыр зацелованный флаг, Я полцарства отдам за коня
}

(Цой, 2009: 129).

В 1988 г. в одном из интервью В. Р. Цой высказал следующую точку зрения: «В нашей рок-музыке много подражательного. Слишком много. А я считаю, что коль скоро музыка эта сочиняется в России, то хоть какие-то элементы русского фольклора присутствовать в ней должны» (там же: 243). Таким образом, ничего удивительного, на наш взгляд, что он использовал именно данный вариант, с которым он мог позна- 
комиться в достаточно значительном числе книг (и совсем необязательно это был Шекспир), услышать в какой-либо театральной постановке или даже, возможно, почерпнуть из следующего анекдота:

Актер, исполняющий роль Ричарда, кричит:

- Коня! Коня! Полцарства за коня!

Раздался голос с галерки:

- А осел подойдет?

- Сойдет и осел, мой друг! Иди сюда!

(цит. по: Актер, исполняющий роль ... : Электронный ресурс)

Наконец, на альбоме «Естественный выбор» 2011 г. отечественной рок-группы «Монгол Шуудан» вышла песня «Полцарства за коня» (музыка и слова В. Е. Скородеда) со следующим припевом, написанном в духе анархизма:

Полцарства за коня! А нас уже и так

Осталося всего не очень много.

Всех нас на кострах сожгут,

И будет Вам отрадно.

Полцарства за коня! И песню нам поют,

Что мы уже давно враги народа.

Нам могилы раздадут

Почти за так, бесплатно

(цит. по: Монгол Шуудан ... : Электронный ресурс).

\section{ЗАКАЮЧЕНИЕ}

Обозначенные примеры хорошо демонстрируют, как вольность переводчика иногда может способствовать более широкому распространению его варианта передачи оригинала в инокультурной среде. Такой перевод может восприниматься читателем и зрителем как более близкий и понятный, а актерами и музыкантами - как более благозвучный и «удобный». Поскольку результат полнее соответствует культурному коду языка перевода, то выбор более известного, устоявшегося варианта повышает шансы того или иного произведения (или отдельного его тезиса) преодолеть тезаурусную мембрану аудитории и войти в тезаурус бо́льшего числа людей (см., например: Куницына, 2009).

Все перечисленные примеры демонстрируют, что Шекспир «вошел в плоть и кровь русского общества ${ }^{4}$. Но этот случай интересен еще и тем, что большое количество произведений различных жанров, в которых можно встретить данный перевод крылатого выражения из шекспировского «Ричарда III», говорит о том, что неточный вариант Я. Г. Брянского с течением времени превратился в эптоним, поскольку довольно часто «используется в иных, нежели его прототип, контекстах и с иными целями» (Аядечко, 2016: 6).

Пример данной шекспировской фразы хорошо демонстрирует, чем крылатые выражения (эптонимы) отличаются, например, от афоризмов и максим: они «обычно более коротки и менее устойчивы, в них допускаются словесные и композиционные замены, что приближает их к фольклору» (Ауков Вл., Ауков В., 2009: 235). Отметим также, что в данном случае слово «конь» иногда заменяется на другое (Ашукин, Ашукина, 1955: 278), а слово «полцарства» опять же обычно остается5 
Таким образом, отклонение Я. Г. Брянского от прототипа исходного текста придало выражению значительную вербальную силу и экспрессивность, благодаря которым оно укоренилось в тезаурусе русской культуры. В некоторых случаях связь с первоисточником не очевидна, и есть вероятность того, что авторы, использовавшие это выражение в своем творчестве, вполне могли почерпнуть его из более поздних источников, не зная, что автор оригинала - знаменитый британский драматург.

\section{ПРИМЕЧАНИЯ}

1 Об элементах и структуре тезауруса см. подробнее: Ауков, В., Ауков, Вл., 2008b: 107-187; 2013: 71-119.

2 Как известно, сам термин «крылатые слова» принадлежит Георгу Бюхману (Georg Büchmann), который именно так перевел выражение в̈ $\pi \varepsilon \alpha \pi \tau \varepsilon \rho \delta ́ \varepsilon \nu \tau \alpha$, часто встречающиеся в «Илиаде» и «ОАиссее» Гомера, на немецкий язык ("Geflügelte Worte") и опубликовал одноименную книгу в 1864 г. (Büchmann, 1864). См., например: Ашукин, Ашукина, 1955: 3; 1988: 4; Ауков ВА., Ауков, В., 2009, 2011.

${ }^{3}$ См., например, воспоминания В. Б. Смехова, сыгравшего роль сэра Кэтсби в постановке П. $\Lambda$. Монастырского в Куйбышевском театре драмы им. Горького (ныне - Самарский академический театр драмы имени М. Горького): «Всему миру известна истошная фраза Ричарда: “Коня, коня! Полцарства за коня!" Здесь у нас на втором плане звучала музыка Вагнера. А кто ее предложил постановщику, а кто принес из дому свою пластинку с записью "Валькирии" и “Тангейзера"? Сами понимаете, я. Вагнер звучит роково и жестоко. Ричард мечется по сцене, требуя коня взамен за полгосударства, а верный Кэтсби - и никто иной! - отвечает на всемирно популярную реплику: “Спасайтесь, государь! Коня достану!” (Смехов, 1986: 283-284).

${ }^{4}$ Слова Ф. М. Аостоевского о Ф. Шиллере. Шекспир, по его мнению, «тоже» стал для русских «родным». См.: Аостоевский, 1993: 102; см. также: Захаров, Ауков, 2009: 101.

5 Так, в повести А. П. Чехова «Три года» (1895) находим следующие слова Полины Николаевны Рассудиной:

- Полцарства за стакан чаю! - проговорила она глухим голосом, закрывая рот муфтой, чтобы не простудиться (Чехов, 1977: 42).

Аругой пример - стихотворение В. П. Катаева «Современник» (1922), в котором нашли отражение воспоминания и впечатления писателя о годах Гражданской войны:

Апрель дождем опился в дым,

И в лоск влюблен любой.

- Полжизни за стакан воды!

- Полцарства за любовь!

$<\ldots>$

И если письмами окрест

Заваливало фронт зимой:

- Полжизни за солдатский крест!

- Полцарства за письмо!

$<\ldots>$

И, трижды бредом лазарет

Пугая, с койки рвался в бой:

- Полжизни за вишневый цвет!

- Полцарства за покой!

$<\ldots>$

И в гром погромов, в перья, в темь,

В дуэли бронепоездов:

- Полжизни за Московский Кремль!

- Полцарства за Ростов! 
$<\ldots>$

Полжизни - раз, четыре, шесть...

Полцарства - шесть - давал обет, -

Ни царств, ни жизней - нет, не счесть,

Ни царств, ни жизней нет...

И только вьюги белый дым,

И только льды в очах любой:

- Полцарства за стакан воды!

- Полжизни за любовь!

(Катаев, 1986: 640-641)

\section{СПИСОК АИТЕРАТУРЫ}

Актер, исполняющий роль Ричарда, кричит: - Коня! Коня!.. [Электронный ресурс]// Анекдоты из России. URL: https://anekdot.ru/id/571417/ (дата обращения: 21.03.2017).

Амфитеатров, А. В. (1903) Житейская накипь : [Очерки и рассказы]. СПб. : Тов. «Общественная польза». [6], 284 с.

Ашукин, Н. С., Ашукина, М. Г. (1955) Крылатые слова : Аитературные цитаты ; Образные выражения. М. : Гослитиздат. 668 с.

Ашукин, Н. С., Ашукина, М. Г. (1988) Крылатые слова : Аитературные цитаты; Образные выражения. 4-е изд., доп. М. : Художественная литература. 528 с.

Баевский, В. С. (1986) О театральных строфах «Евгения Онегина» // Временник Пушкинской комиссии / АН СССР. Отделение лит. и яз. Пушкин. комис. $\Lambda$. : Наука. Аенингр. отд-ние. Вып. 20.214 с. С. $139-150$.

Бахнов, В. Е. (1973) Савушкин, который никому не верил // Клуб 12 стульев : сборник. [По материалам «Иит. газеты»]. М. : Искусство. 302 с. С. 29-35.

Быков, В. В. (1985) Журавлиный крик : повесть / пер. В. Рудовой // Быков, В. В. Собр. соч. : в 4 т. М. : Молодая гвардия. Т. 1. 414 с. С. 25-110.

«Вечные» сюжеты и образы в литературе и искусстве русского модернизма (2015)/ отв. ред. А. $\Lambda$. Топорков. М. : Индрик. 416 с.

Волкова, Е. И. (2008) Вечные сюжеты и образы культуры: мифология - Библия - литература (Россия, Западная Европа, США) // Вопросы гуманитарных наук. № 1 (34). С. 103-119.

Всеобщая история, обработанная «Сатириконом» (2005)// Юмор начала XX века : сборник. М. : ОАМА-ПРЕСС Звездный мир. 600 с. С. 469-595.

Гайдин, Б. Н. (2008) Вечные образы как константы культуры // Знание. Понимание. Умение. № 2. C. 241-245.

Гайдин, Б. Н. (2009а) Вечные образы в системе констант культуры // Знание. Понимание. Умение. № 2. С. 224-230.

Гайдин, Б. Н. (2009b) Вечные образы как константы культуры (интерпретация «гамлетовского вопроса») : автореф. дис. ... канд. филос. наук. М. 17 с.

Гайдин, Б. Н. (2009c) Вечные образы как константы культуры (интерпретация «гамлетовского вопроса») : дис. ... канд. филос. наук. М. 194 с.

Гайдин, Б. Н. (2009d) Вечные образы как критерий «значимости» литературных произведений // Высшее образование для XXI века : VI Международная научная конференция. Москва, 19-21 ноября 2009 г. : доклады и материалы. Ч. I / под общ. ред. И. М. Ильинского. М. : Изд-во Моск. гуманит. ун-та. 320 с. С. 197-204.

Гайдин, Б. Н. (2011) Вечные образы как константы культуры: тезаурусный анализ «гамлетовского вопроса». Saarbrücken : Lambert Academic Publishing. 212 c.

Григорьев, А. А. (2001) Искусство и правда // Григорьев, А. А. Стихотворения. Поэмы. Арамы / подг. текста, сост., вступ. статья и примеч. Б. Ф. Егорова. СПб. : Академический проект. 760 c. C. $110-116$. 
Аостоевский, Ф. М. (1993) Книжность и грамотность Статья первая // Аостоевский, Ф. М. Собрание сочинений : в 15 т. СПб. : Наука. Т. 11: Публицистика 1860-х годов. 571, [1] с. C. 88-105.

Аюма, А. (1992) Собрание сочинений : в 35 т. М. : ММП «Аайджест». Т. 4: Королева Марго : роман / пер. с фр. Е. Корша ; сост. А. Кукаркин ; коммент. И. Пожаровой. 512 с.

Аюма, А. (2014) Королева Марго / пер. с фр. Я. Глумберга. Montreal : Accent Graphics Communications ; Literary Heritage.

Аядечко, А. П. (2002) Крылатые слова как объект лингвистического описания: история и современность. Киев : ИПЦ «Київ. ун-т». 291 с.

Аядечко, А. П. (2003) Крилаті слова в російській мові: системно-функціональний та лексикографічний аспекти : автореф. ... А-ра филол. наук. Киев. 34 с.

Аядечко, А. П. (2006) Основные принципы современной эптографии // Славянские языки в свете культуры : сб. ст. / Ин-т рус. яз. им. В. В. Виноградова РАН ; отв. ред. М. А. Алексеенко. М. : А Темп. 348, [1] с. С. 188-204.

Аядечко, А. П. (2016) Фразеологическая судьба главного коммунистического лозунга в восточнославянских языках // Проблемы истории, филологии, культуры. № 3 (53). С. 5-12. DOI: 10.18503/1992-0431-2016-3-53-5-12

Захаров, Н. В., Ауков, Вл. А. (2009) Шекспир и шекспиризм в России // Знание. Понимание. Умение. № 1. С. 98-106.

Ибсен, Г. (1909) Пер Гюнт. Араматическая поэма в пяти действиях // Полн. собр. соч. Генрика Ибсена / пер. с датско-норвежского А. и П. Ганзен. СПб. : Изд. Т-ва А. Ф. Маркса. Т. І. 633 c. C. $246-397$.

Ибсен, Г. (1972) Пер Гюнт. Араматическая поэма в пяти действиях / пер. П. М. Карпа // Ибсен, Г. Арамы. Стихотворения. М. : Художественная литература. 815 с. С. 23-234. (Библиотека всемирной литературы. Сер. вторая. Т. 87).

Катаев, В. П. (1986) Современник // Катаев, В. П. Собрание сочинений : в 10 т. М. : Худож. лит. Т. 10: Горох в стенку: Юмористические рассказы, фельетоны; Почти дневник; Стихотворения; Спящий. 711 с. С. 639-641.

Кельсиев, В. И. (1868) Пережитое и передуманное : Воспоминания Василия Кельсиева. СПб. : Печатня В. Головина. [4], 443 с.

Куницына, Е. Ю. (2009) Арама Шекспира: сценичность перевода и переводческий дискурс // Вестник Иркутского государственного лингвистического университета. № 4 (8). С. 48-56.

Аажечников, И. И. (1989) Басурман : роман ; Колдун на Сухаревой башне : отрывок из романа ; Очерки-воспоминания / сост., вступ. статья, примеч. Н. Г. Ильинской. М. : Советская Россия. 528 с.

Иевин, Ю. А. (1965) Русский романтизм // Шекспир и русская культура / под ред. акад. М. П. Алексеева. М. ; $\Lambda$. : Наука. 832 с. С. 201-315.

Ауков, В. А., Ауков, Вл. А. (2008а) Вечные образы как константы тезаурусов мировой культуры [Электронный ресурс] // Информационный гуманитарный портал «Знание. Понимание. Умение». №9 - Комплексные исследования: тезаурусный анализ мировой культуры. URL: http://zpu-journal.ru/e-zpu/2008/9/Lukovs_Eternal_Images/(дата обращения: 22.03.2017).

Ауков, В. А., Ауков, Вл. А. (2008b) Тезаурусы: Субъектная организация гуманитарного знания. М. : ИзА-во Нац. ин-та бизнеса. 784 с.

Ауков, В. А., Ауков, Вл. А. (2013) Тезаурусы II: Тезаурусный подход к пониманию человека и его мира. М. : Нац. ин-т бизнеса. 640 с.

Иуков, Вл. А., Ауков, В. А. (2009) Крылатые слова // Знание. Понимание. Умение. № 2. C. 235-238.

Ауков, Вл. А., Ауков, В. А. (2011) Крылатые слова // Новая российская энциклопедия : в 12 т. / редкол.: А. А. Некипелов, В. И. Аанилов-Аанильян и др. М. : Энциклопедия ; ИНФРА-М. T. IX (1): Костелич - Магос-де-Морено. 478, [1] с. С. 219-221.

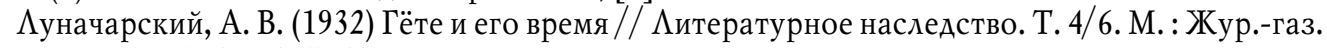
объединение. 1062 с. С. 5-20. 
ムьвов, А. (1991а) Авор : роман (начало) // Аружба народов. № 2. С. 110-140.

Аьвов, А. (1991b) Авор : роман (продолжение) // Аружба народов. № 3. С. 120-155.

Аьвов, А. (1991с) Авор : роман (окончание) // Аружба народов. № 4. С. 121-156.

Марлинский, А. (1835) Аорога от станции Алмалы до поста Мугансы // Библиотека для чтения. Т. XII. С. 20-34.

Мельниченко, И. М. (1982) Полцарства за коня : повесть. Киев : Радянський письменник. 197 с.

Монгол Шуудан - Полцарства за коня [Электронный ресурс] // Megalyrics. URL: http://megalyrics.ru/lyric/monghol-shuudan/poltsarstva-za-konia.htm (дата обращения: 21.03.2017).

Мухина, О. И. (1983) «Аистаю книгу города...». «Ночь над землей, мой шепот тих...». «Ночью выпала пороша...». Ожидание. «Как перепутаны следы...». «Средь свиста стрел и пиршества булата...». Стихи // Сибирские огни. № 10. С. 38-39.

Николаев, А. А. (2012) Вечные образы в драматургии русского зарубежья // Славянские языки и культуры в современном мире : труды и материалы II Международного научного симпозиума (Москва, МГУ имени М. В. Аомоносова, филологический факультет, 21-24 марта 2012 г.) / сост.: О. В. Аедова, А. М. Захаров, К. В. Аифанов ; под общ. рук. М. А. Ремнёвой. М. : ИзА-во Моск. гос. ун-та. 405, [1] с. С. 176-177.

Олейникова, Т. И. (1992) Прощай : юношеская поэма // Олейникова, Т. И. Спаси себя, человече : Избранные стихи и поэмы. [Белгород] : Осколинформ. 231 с. С. 195-203.

Салахатдинова, Э. Ш. (2014) Семантизация крылатых слов разных типов в русской лексикографии // Филология и культура. № 1 (35) С. 94-99.

Смехов, В. Б. (1986) В один прекрасный день... : В один прекрасный день ; Из детского ящика ; Записки на кулисах ; Пейзажи и портреты : повести, рассказы, зарисовки. М. : Советский писатель. 423 с.

Тургенев, И. С. (1978) Помещик // Тургенев, И. С. Полн. собр. соч. и писем : в 30 т. Соч. : в 12 т. 2-е изА., испр. и доп. М. : Наука. Т. 1: Стихотворения, поэмы, статьи и рецензии, прозаические наброски. 1834-1849. 573 с. С. 153-172.

Тургенев, И. С. (1986) <Речь о Шекспире> // Тургенев, И. С. Полное собрание сочинений и писем : в 30 т. Соч. : в 12 т. 2-е изд., испр. и доп. М. : Наука. Т. 12: Аибретто комических опер; Водевиль; Стихотворения; Речи; Записки общественного назначения; Автобиографическое; Незавершенное; DUBIA, 1840-1883; Указатели. 813, [1] с. С. 325-328.

Урнов, А. М. (2011) На благо лошадей : конный мир за последние семьдесят лет : очерки иппические [Электронный ресурс]. М. : Изд-во им. Сабашниковых.

Уэллс, Г. (1964) Колёса фортуны // Уэллс, Г. Собр. соч. : в 15 т. М. : Правда. Т. 8. 592 с. C. $413-590$.

Цой, В. Р. (2009) Звезды останутся здесь / авт.-сост. А. А. Жавнерович. М. : Эксмо. 349, [1] с.

Чехов, А. П. (1977) Три года // Чехов, А. П. Полн. собр. соч. и писем : в 30 т. Соч. : в 18 т. / АН СССР. Ин-т мировой лит. им. А. М. Горького. М. : Наука. Т. 9: Рассказы. Повести, 1894-1897. 544 c. С. 7-91.

Шекспир, В. (1899) Король Ричард Третий. Араматическая хроника в пяти действиях / пер. А. В. Аружинина // Полн. собр. соч. В. Шекспира в переводе русских писателей : в 3 т. / под ред. А. А. Михаловского. 5-е изд. СПб. : Изд. Н. В. Гербеля. Т. 2. С. 387-442.

Шекспир, В. (1958) Король Ричард Третий : трагедия в пяти актах / пер. Б. Н. Аейтина под ред. Е. Н. Бируковой. М. : Гос. изА-во худож. лит-ры. 171 с.

Шекспир, В. (1988) Король Ричард III / пер. М. А. Аонского // Шекспир, В. Комедии. Хроники. Трагедии : в 2 т. / вступ. ст., сост., коммент. А. М. Урнова. М. : Худож. лит. Т. 1. 783 с. С. 301-452.

Шекспир, У. (1936) Трагедия о Гамлете, принце Аатском / пер. М. А. Аозинского // Шекспир, В. Полное собрание сочинений : в 8 т. / под общ. ред. С. С. Аинамова, А. А. Смирнова. М. ;

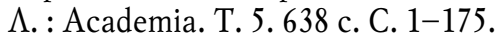

Шекспир, У. (1957) Ричард III / пер. А. А. Радловой // Шекспир У. Полн. собр. соч. : в 8 т. / под общ. ред. А. А. Смирнова, А. А. Аникста. М. : Искусство. Т. 1. 615 с. С. 431-579. 
Шекспир, У. (1997) Король Ричард III : трагедия в 5 актах / пер. Г. Е. Бена. СПб. : Изд-во журн. «Звезда». 234, [4] с.

Шестов, А. И. (1898) Шекспир и его критик Брандес. СПб. : Тип. А. М. Менделевича. 282 с.

Шулежкова, С. Г. (2011) И жизнь, и слёзы, и любовь... : происхождение, значение, судьба 1500 крылатых слов и выражений русского языка. М. : Флинта ; Наука. 846, [1] с.

Шульгин, В. В. (2002) Годы. Воспоминания члена Государственной Аумы // Шульгин, В. В. Последний очевидец : Мемуары. Очерки. Сны / сост., вступ. ст., послесл. Н. Н. Аисового. М. : ОАМА-ПРЕСС Звездный мир. 587, [1] с. С. 23-430.

Энциклопедический словарь крылатых слов и выражений (2005) : более 4000 ст. / авт.-сост. В. Серов. 2-е изд. М. : Аокид-Пресс. 880 с.

Aphorisms from Shakespeare (1812) : arranged according to the plays, \&c. with a preface and notes ; numeral references to each subject ; and a copious index / W. Shakespeare; ed. by C. Lofft. L. : Printed for Longman, Hurst, Rees, Orme, and Brown, by Gedge and Barker, Bury. xxxiv, [2], 456, xxxvi p.

Büchmann, G. (1864) Geflügelte Worte: Der Citatenschatz des deutschen Volks. Berlin : Haude und Spener. $220 \mathrm{~s}$.

Dumas, A. (1847) La reine Margot : 2 vols. in 1. Paris : M. Lévy Frères. Vol. I. 323 p.

Goethes Gespräche (1909) : Gesamtausgabe : im 5 Bds. / J. W. von Goethe. Leipzig : F. W. von Biedermann. Bd. 2: Vom Erfurter Kongreß bis zum letzten böhmischen Aufenthalt. $667 \mathrm{~s}$.

Ibsen, H. (1867) Peer Gynt : Et dramatisk Digt. Kjøbenhavn : Forlagt av den Gyldendalske Boghandel (F. Hegel.). $259 \mathrm{~s}$.

Logeman, H. (1917) A commentary, critical and explanatory, on the Norwegian text of Henrik Ibsen's Peer Gynt, its language, literary associations, and folklore. The Hague : Martinus Nijhoff. xiv, $484 \mathrm{p}$.

McQuain, J., Malless, S. (1998) Coined by Shakespeare : words and meanings first used by the Bard. Springfield, MA : Merriam-Webster. xii, 273 p.

The Arden dictionary of Shakespeare quotations (2013) / W. Shakespeare; comp. by J. Armstrong. L. : Bloomsbury UK. xii, 396 p.

Wells, H. G. (1896) The wheels of chance: A holiday adventure. L. : J. M. Dent ; N. Y. : Macmillan Co. xiii, 313 p.

Аата поступления: 29.03.2017 2.

"A HORSE! A HORSE! MY KINGDOM FOR A HORSE!": A LOOSE TRANSLATION OF SHAKESPEAREAN CATCH PHRASE IN THE THESAURUS OF RUSSIAN CULTURE

\section{B. N. GAYDIN}

\section{MOSCOW UNIVERSITY FOR THE HUMANITIES}

The article examines the problem of academic description of winged words and catch phrases within the scope of the thesaurus approach. The author briefly presents L. P. Diadechko's conception of the term "eptonym". This gives an opportunity to fortify some conclusions about the specific character of this type of cultural constants.

The author traces the fate of a loose Russian translation of the well-known cry of King Richard III "A horse! a horse! my kingdom for a horse!" $(\mathrm{V}, 4)$ in the eponymous historical play by W. Shakespeare. The article presents extracts from literary works written in the 19th-21st centuries as well as from lyrics of two songs where the translation attributed to the Russian actor Ya. G. Brianskiy can be found. Its influence on other translators is analyzed. In the author's opinion, the inaccuracy of the rendition of Shakespeare's original (literally "A horse! a horse! A half of kingdom for a horse!") has contributed to the diffusion of this eptonym in Russian cultural thesaurus. This example also shows that in contrast to aphorisms and maxims winged words (eptonyms) can have different meanings in various contexts as well as they can be verbally transformed.

The main points of the article were presented at the 2nd Academic Readings in the memory of Vladimir Andreyevich Lukov "Thesauri and Thesaurus Sphere" (Moscow University for the Humanities, March 29, 2017). 
Keywords: W. Shakespeare; Shakespeare in Russia; "Richard III"; thesaurus approach; thesaurus of Russian culture; translations of Shakespeare's works; Ya. G. Brianskiy; winged words; catch phrases; eptonym

\section{REFERENCES}

Akter, ispolniaiushchii rol' Richarda, krichit: - Konia! Konia!.. Anekdoty iz Rossii [online] Available at: https://anekdot.ru/id/571417/ (accessed 21.03.2017). (In Russ.).

Amfiteatrov, A. V. (1903) Zhiteiskaia nakip' : [Essays and short stories]. St. Petersburg, Tovarishchestvo "Obshchestvennaia pol'za". [6], 284 p. (In Russ.).

Ashukin, N. S. and Ashukina, M. G. (1955) Krylatye slova : Literaturnye tsitaty; Obraznye vyrazheniia. Moscow, Goslitizdat Publ. 668 p. (In Russ.).

Ashukin, N. S. and Ashukina, M. G. (1988) Krylatye slova : Literaturnye tsitaty; Obraznye vyrazheniia. 4th edn., enlarged. Moscow, Khudozhestvennaia literatura Publ. 528 p. (In Russ.).

Baevskii, V. S. (1986) O teatral'nykh strofakh "Evgeniia Onegina". In: Vremennik Pusbkinskoi komissii. Leningrad, Nauka Publ. Issue 20. 214 p. Pp. 139-150. (In Russ.).

Bakhnov, V. E. (1973) Savushkin, kotoryi nikomu ne veril. In: Klub 12 stul' ev : A collection. Moscow, Iskusstvo Publ. 302 p. Pp. 29-35. (In Russ.).

Bykov, V. V. (1985) Zhuravlinyi krik : A short novel / transl. by V. Rudova. In: Bykov V. V. Sobranie socbinenii : in 4 vols. Moscow, Molodaia gvardiia Publ. Vol. 1. 414 p. Pp. 25-110. (In Russ.).

"Vechnye" siuzhety $i$ obrazy $v$ literature $i$ iskusstve russkogo modernizma (2015) / ed. by A. L. Toporkov. Moscow, Indrik Publ. 416 p. (In Russ.).

Volkova, E. I. (2008) Vechnye siuzhety i obrazy kul'tury: mifologiia - Bibliia - literatura (Rossiia, Zapadnaia Evropa, SShA). Voprosy gumanitarnykb nauk, no. 1 (34), pp. 103-119. (In Russ.).

Vseobshchaia istoriia, obrabotannaia "Satirikonom". (2005) In: Iumor nachala XX veka : A collection. Moscow, OLMA-PRESS Zvezdnyi mir Publ. 600 p. Pp. 469-595. (In Russ.).

Gaydin, B. N. (2008) Vechnye obrazy kak konstanty kul'tury. Znanie. Ponimanie. Umenie, no. 2, pp. 241-245. (In Russ.).

Gaydin, B. N. (2009a) Vechnye obrazy v sisteme konstant kul'tury. Znanie. Ponimanie. Umenie, no. 2, pp. 224-230. (In Russ.).

Gaydin, B. N. (2009b) Vechnye obrazy kak konstanty kul'tury (interpretatsiia "gamletovskogo voprosa" ) : Abstract of the diss. ... Candidate of Philosophy. Moscow. 17 p. (In Russ.).

Gaydin, B. N. (2009c) Vechnye obrazy kak konstanty kul'tury (interpretatsiia "gamletovskogo voprosa" ) : Diss. ... Candidate of Philosophy. Moscow. 194 p. (In Russ.).

Gaydin, B. N. (2009d) Vechnye obrazy kak kriterii "znachimosti" literaturnykh proizvedenii. In: Vyssbee obrazovanie dlia XXI veka : VI mezhdunarodnaia nauchnaia konferentsiia. Moskva, 19-21 noiabria 2009 g. : Papers and proceedings. Pt. I / ed. by. I. M. Ilinskiy. Moscow, Moscow University for the Humanities Publ. 320 p. Pp. 197-204. (In Russ.).

Gaydin, B. N. (2011) Vechnye obrazy kak konstanty kul' tury: tezaurusnyi analiz "gamletovskogo voprosa". Saarbrücken, Lambert Academic Publishing. 212 p. (In Russ.).

Grigoriev, A. A. (2001) Iskusstvo i Pravda. In: Grigoriev, A. A. Stikbotvoreniia. Poemy. Dramy / prepared, comp., foreword and notes by B. F. Egorov. St. Petersburg, Akademicheskii proekt Publ. 760 p. Pp. 110-116. (In Russ.).

Dostoevsky, F. M. (1993) Knizhnost' i gramotnost' Stat'ia Pervaia. In: Dostoevsky, F. M. Sobranie sochinenii : in 15 vols. St. Petersburg, Nauka Publ. Vol. 11: Publitsistika 1860-kb godov. 571, [1] p. Pp. 88-105. (In Russ.).

Dumas, A. (1992) Sobranie socbinenii : in 35 vols. Moscow, Daidzhest Publ. Vol. 4: Koroleva Margo : A novel / transl. from French by E. Korsh ; comp. by A. Kukarkin ; comm. by I. Pozharova. 512 p. (In Russ.).

Dumas, A. (2014) Koroleva Margo / transl. from French Ya. Glumberg [Computer file]. Montreal, Accent Graphics Communications ; Literary Heritage. (In Russ.). 
Diadechko, L. P. (2002) Krylatye slova kak ob" ekt lingvisticheskogo opisaniia: istoriia $i$ sovremennost'. Kiev, Kiev University Publ. 291 p. (In Russ.).

Diadechko, L. P. (2003) Krilati slova $v$ rosiis'kii movi: sistemno-funktsional'nii ta leksikografichnii aspekti : Abstract of the diss. ... Doctor of Philology. Kiev. 34 p. (In Ukr.).

Diadechko, L. P. (2006) Osnovnye printsipy sovremennoi eptografii. In: Slavianskie iazyki v svete kul'tury: A collection of articles / ed. by M. A. Alekseenko. Moscow, A Temp Publ. 348, [1] p. Pp. 188-204. (In Russ.).

Diadechko, L. P. (2016) Frazeologicheskaia sud'ba glavnogo kommunisticheskogo lozunga v vostochnoslavianskikh iazykakh. Problemy istorii, filologii, kul'tury, no 3 (53), pp. 5-12. DOI: 10.18503/1992-0431-2016-3-53-5-12 (In Russ.).

Zakharov, N. V. and Lukov, Vl. A. (2009) Shekspir i shekspirizm v Rossii. Znanie. Ponimanie. Umenie, no. 1, pp. 98-106. (In Russ.).

Ibsen, H. (1909) Per Giunt. Dramaticheskaia poema v piati deistviiakh. In: Polnoe sobranie socbinenii Genrika Ibsena / transl. from Danish-Norwegian by A. Ganzen and P. Ganzen. St. Petersburg, Izdatel'stvo Tovarishchestva A. F. Marksa. Vol. I. 633 p. Pp. 246-397. (In Russ.).

Ibsen, H. (1972) Per Giunt. Dramaticheskaia poema v piati deistviiakh / transl. by P. M. Karp. In: Ibsen, H. Dramy. Stikhotvoreniia. Moscow, Khudozhestvennaia literatura Publ. 815 p. Pp. 23-234. (Biblioteka vsemirnoi literatury. Second series. Vol. 87). (In Russ.).

Kataev, V. P. (1986) Sovremennik. In: Kataev V. P. Sobranie socbinenii : in 10 vols. Moscow, Khudozhestvennaia literatura Publ. Vol. 10: Gorokb v stenku: Iumoristicheskie rasskazy, fel' etony; Pochti dnevnik; Stikbotvoreniia; Spiashchii. 711 p. Pp. 639-641. (In Russ.).

Kelsiev, V. I. (1868) Perezhitoe i peredumannoe : Vospominaniia Vasiliia Kel'sieva. St. Petersburg, Pechatnia V. Golovina. [4], 443 p. (In Russ.).

Kunitsyna, E. Yu. (2009) Drama Shekspira: stsenichnost' perevoda i perevodcheskii diskurs. Vestnik Irkutskogo gosudarstvennogo lingvisticheskogo universiteta, vol. 4 (8), pp. 48-56. (In Russ.).

Lazhechnikov, I. I. (1989) Basurman : roman; Koldun na Sukbarevoi bashne: otryvok iz romana ; Ocherki-vospominaniia / comp., introduction, notes by N. G. Ilinskaia. Moscow, Sovetskaia Rossiia Publ. 528 p. (In Russ.).

Levin, Yu. D. (1965) Russkii romantizm. In: Shekspir i russkaia kul'tura / ed. by M. P. Alekseev. Moscow ; Leningrad, Nauka Publ. 832 p. Pp. 201-315. (In Russ.).

Lukov, V. A. and Lukov, Vl. A. (2008a) Vechnye obrazy kak konstanty tezaurusov mirovoi kul'tury. Informatsionnyi gumanitarnyi portal "Znanie. Ponimanie. Umenie", no. 9 - Kompleksnye issledovaniia: tezaurusnyi analiz mirovoi kul'tury. [online] Available at: http://zpu-journal.ru/ezpu/2008/9/Lukovs_Eternal_Images/(accessed 22.03.2017). (In Russ.).

Lukov, V. A. and Lukov, Vl. A. (2008b) Tezaurusy: Sub'ektnaia organizatsiia gumanitarnogo znaniia. Moscow, National Institute of Business Publ. 784 p. (In Russ.).

Lukov, V. A. and Lukov, Vl. A. (2013) Tezaurusy II: Tezaurusnyi podkbod k ponimaniiu cheloveka i ego mira. Moscow, National Institute of Business Publ. 640 p. (In Russ.).

Lukov, Vl. A. and Lukov, V. A. (2009) Krylatye slova. Znanie. Ponimanie. Umenie, no. 2, pp. 235-238. (In Russ.).

Lukov, Vl. A. and Lukov, V. A. (2011) Krylatye slova. In: Novaia rossiiskaia entsiklopediia : in 12 vols. / editorial board: A. D. Nekipelov, V. I. Danilov-Danilian et al. Moscow, Entsiklopediia Publ. ; INFRA-M Publ. Vol. IX (1): Kostelich - Lagos-de-Moreno. 478, [1] p. Pp. 219-221. (In Russ.).

Lunacharsky, A. V. (1932) Gete i ego vremia. In: Literaturnoe nasledstvo. Vol. 4/6. Moscow, Zhurnal'no-gazetnoe ob'edinenie. 1062 p. Pp. 5-20. (In Russ.).

Lvov, A. (1991a) Dvor : A novel (the beginning). Druzbba narodov, no. 2, pp. 110-140. (In Russ.).

Lvov, A. (1991b) Dvor: A novel (the continuation). Druzbba narodov, no. 3, pp. 120-155. (In Russ.).

Lvov, A. (1991c) Dvor : A novel (the ending). Druzbba narodov, no. 4, pp. 121-156. (In Russ.).

Marlinsky, A. (1835) Doroga ot stantsii Almaly do posta Mugansy. In: Biblioteka dlia cbteniia, vol. XII, pp. 20-34. (In Russ.). 
Melnichenko, I. M. (1982) Poltsarstva za konia: A short novel. Kiev, Radians'kii pis'mennik Publ. 197 p. (In Russ.).

Mongol Shuudan — Poltsarstva za konia. Megalyrics [online] Available at: http://megalyrics.ru/ lyric/monghol-shuudan/poltsarstva-za-konia.htm (accessed 21.03.2017). (In Russ.).

Mukhina, O. I. (1983) "Listaiu knigu goroda...". "Noch' nad zemlei, moi shepot tikh...". "Noch'iu vypala porosha...". Ozhidanie. "Kak pereputany sledy...". "Sred' svista strel i pirshestva bulata...". Stikhi. Sibirskie ogni, no. 10, pp. 38-39. (In Russ.).

Nikolaev, D. D. (2012) Vechnye obrazy v dramaturgii russkogo zarubezh'ia. In: Slavianskie iazyki i kul'tury $v$ sovremennom mire : Papers and proceedings / comp. by O. V. Dedova, L. M. Zakharov and K. V. Lifanov ; ed. by M. L. Remneva. Moscow, Moscow State University Publ. 405, [1] p. Pp. 176-177. (In Russ.).

Oleinikova, T. I. (1992) Proshchai : iunosheskaia poema. In: Oleinikova, T. I. Spasi sebia, cheloveche : Selected verses and poems. Belgorod, Oskolinform Publ. 231 p. Pp. 195-203. (In Russ.).

Salakhatdinova, E. Sh. (2014) Semantizatsiia krylatykh slov raznykh tipov v russkoi leksikografii. Filologiia i kul'tura, no. 1 (35), pp. 94-99. (In Russ.).

Smekhov, V. B. (1986) Vodin prekrasnyi den'... : Vodin prekrasnyi den' ; Iz detskogo iashchika ; Zapiski na kulisakh ; Peizazbi i portrety : povesti, rasskazy, zarisovki. Moscow, Sovetskii pisatel' Publ. 423 p. (In Russ.).

Turgenev, I. S. (1978) Pomeshchik. In: Turgenev, I. S. Polnoe sobranie sochinenii i pisem : in 30 vols. Sochineniia: in 12 vols. 2nd edn., revised and enlarged. Moscow, Nauka Publ. Vol. 1: Stikhotvoreniia, poemy, stat'i i retsenzii, prozaicheskie nabroski. 1834-1849. 573 p. Pp. 153-172. (In Russ.).

Turgenev, I. S. (1986) <Rech' o Shekspire>. In: Turgenev, I. S. Polnoe sobranie socbinenii i pisem: in 30 vols. Sochineniia : in 12 vols. 2nd edn., revised and enlarged. Moscow, Nauka Publ. Vol. 12: Libretto komicheskikb oper; Vodevil'; Stikhotvoreniia; Rechi; Zapiski obshchestvennogo naznacheniia; Avtobiograficheskoe; Nezavershennoe; DUBIA, 1840-1883; Ukazateli. 813, [1] p. Pp. 325-328. (In Russ.).

Urnov, D. M. (2011) Na blago loshadei : konnyi mir za poslednie sem' desiat let : ocherki ippicheskie [Computer file]. Moscow, Izdatel'stvo imeni Sabashnikovykh. (In Russ.).

Wells, H. G. (1964) G. Kolesa fortuny. In: Wells, H. G. Sobranie sochinenii : in 15 vols. Moscow, Pravda Publ. Vol. 8. 592 p. Pp. 413-590. (In Russ.).

Tsoi, V. R. (2009) Zvezdy ostanutsia zdes' / comp. by A. A. Zhavnerovich. Moscow, Eksmo Publ. 349, [1] p. (In Russ.).

Chekhov, A. P. (1977) Tri goda. In: Chekhov, A. P. Polnoe sobranie sochinenii i pisem : v 30 vols. Socbineniia : in 18 vols. Moscow, Nauka Publ. Vol. 9: Rasskazy. Povesti, 1894-1897. 544 p. Pp. 7-91. (In Russ.).

Shakespeare, W. (1899) Korol' Richard Tretii. Dramaticheskaia khronika v piati deistviiakh / transl. by A. V. Druzhinin. In: Polnoe sobranie socbinenii V. Shekspira v perevode russkikb pisatelei : v 3 t. /ed. by D. L. Mikhalovskii. 5nd edn. St. Petersburg, Izdatel'stvo N. V. Gerbelia. Vol. 2. Pp. 387-442. (In Russ.).

Shakespeare, W. (1958) Korol' Richard Tretii : tragediia v piati aktakb / transl. by B. N. Leitin ed. by E. N. Birukova. Moscow, Gosudarstvennoe izdatel'stvo khudozhestvennoi literatury. 171 p. (In Russ.).

Shakespeare, W. (1988) Korol' Richard III / transl. by M. A. Donskoi. In: Shakespeare, W. Komedii. Khroniki. Tragedii : in 2 vols. / introduction, comp., notes by D. M. Urnov. Moscow, Khudozhestvennaia literatura Publ. Vol. 1.783 p. Pp. 301-452. (In Russ.).

Shakespeare, W. (1936) Tragediia o Gamlete, printse Datskom / transl. by M. L. Lozinsky. In: Shakespeare, W. Polnoe sobranie sochinenii : in 8 vols. / ed. by S. S. Dinamov and A. A. Smirnov. Moscow ; Leningrad, Academia Publ. Vol. 5.638 p. Pp. 1-175. (In Russ.).

Shakespeare, W. (1957) Richard III / transl. by A. D. Radlova. In: Shakespeare, W. Polnoe sobranie sochinenii : in 8 vols. / ed. by A. A. Smirnov and A. A. Anikst. Moscow, Iskusstvo Publ. Vol. 1. 615 p. Pp. 431-579. (In Russ.). 
Shakespeare, W. (1997) Korol' Richard III : tragediia $v 5$ aktakb / transl. by G. E. Ben. St. Petersburg, Izdatel'stvo zhurnala "Zvezda". 234, [4] p. (In Russ.).

Shestov, L. I. (1898) Shekspir i ego kritik Brandes. St. Petersburg, Tipagrafiia A. M. Mendelevicha. 282 p. (In Russ.).

Shulezhkova, S. G. (2011) I zbizn', i slezy, i liubov'... : proiskbozbdenie, znachenie, sud'ba 1500 krylatykh slov i vyrazhenii russkogo iazyka. Moscow, Flinta Publ. ; Nauka Publ. 846, [1] p. (In Russ.).

Shulgin, V. V. (2002) Gody. Vospominaniia chlena Gosudarstvennoi Dumy. In: Shulgin, V. V. Poslednii ochevidets : Memuary. Ocherki. Sny / comp., opening chapter, afterword by N. N. Lisovoi. Moscow, OLMA-PRESS Zvezdnyi mir Publ. 587, [1] p. Pp. 23-430. (In Russ.).

Entsiklopedicheskii slovar' krylatykb slov i vyrazbenii (2005) : more than 4,000 words / comp. by V. Serov. 2nd edn. Moscow, Lokid-Press. 880 p. (In Russ.).

Aphorisms from Shakespeare (1812) : arranged according to the plays, \&c. with a preface and notes ; numeral references to each subject ; and a copious index / W. Shakespeare; ed. by C. Lofft. London, Printed for Longman, Hurst, Rees, Orme, and Brown, by Gedge and Barker, Bury. xxxiv, [2], 456, xxxvi p. (In Russ.).

Büchmann, G. (1864) Geflü̈gelte Worte: Der Citatenschatz des deutschen Volks. Berlin, Haude und Spener. 220 s. (In Germ.).

Dumas, A. (1847) La reine Margot : 2 vols. in 1. Paris, M. Lévy Frères. Vol. I. 323 p. (In Fr.).

Goethes Gespräche (1909) : Gesamtausgabe : im 5 Bds. / J. W. von Goethe. Leipzig, F. W. von Biedermann. Bd. 2: Vom Erfurter Kongreß bis zum letzten böbmischen Aufentbalt. 667 p. (In Germ.).

Ibsen, H. (1867) Peer Gynt : Et dramatisk Digt. Kjøbenhavn : Forlagt av den Gyldendalske Boghandel (F. Hegel.). 259 p. (In Norw.).

Logeman, H. (1917) A commentary, critical and explanatory, on the Norwegian text of Henrik Ibsen's Peer Gynt, its language, literary associations, and folklore. The Hague, Martinus Nijhoff. xiv, $484 \mathrm{p}$.

McQuain, J. and Malless, S. (1998) Coined by Shakespeare : words and meanings first used by the Bard. Springfield, MA, Merriam-Webster. xii, 273 p.

The Arden dictionary of Shakespeare quotations (2013) / W. Shakespeare; comp. by J. Armstrong. London, Bloomsbury UK. xii, 396 p.

Wells, H. G. (1896) The wheels of chance: A boliday adventure. London, J. M. Dent ; New York, Macmillan Co. xiii, 313 p.

Submission date: 29.03 .2017$.

Гайдин Борис Николаевич - кандидат философских наук, начальник научно-исследовательского отдела цифровых технологий Центра теории и истории культуры Института фундаментальных и прикладных исследований Московского гуманитарного университета, член-корреспондент Международной академии наук (IAS, Инсбрук). Адрес: 111395, Россия, г. Москва, ул. Юности, 5, корп. 6. Тел.: +7 (499) 374-59-30. Эл. алpec: bngaydin@mosgu.ru

Gaydin Boris Nikolaevich, Candidate of Philosophy, Head of the Research Department of Digital Technologies, Center for the Theory and History of Culture, Institute of Fundamental and Applied Studies, Moscow University for the Humanities; Associate Member, International Academy of Science (IAS, Innsbruck). Postal address: Bldg. 6, 5 Yunosti St., Moscow, Russian Federation, 111395. Tel.: +7 (499) 374-59-30. E-mail: bngaydin@mosgu.ru 